\title{
An unexpected 1,2-alkyl shift within a chelate bonded organoaluminium-enamine *
}

\author{
Elmo Wissing, Johann T.B.H. Jastrzebski, Jaap Boersma and Gerard van Koten \\ Debye Institute, Department of Metal-Mediated Synthesis, Utrecht University, Padualaan 8, 3584 CH Utrecht (Netherlands)
}

(Received May 6, 1993)

\begin{abstract}
The organozinc-enamines $\mathrm{EtZn}\left[\mathrm{R}^{\prime} \mathrm{N}-\mathrm{CH}=\mathrm{CH}-\mathrm{N}(\mathrm{Et}) \mathrm{R}^{\prime}\right]\left(\mathrm{R}={ }^{\mathrm{t}} \mathrm{Bu}(\mathbf{1 a}),{ }^{\mathrm{t}}\right.$ pent (2a), $\left.{ }^{\mathrm{i}} \mathrm{Pr}(3 \mathrm{a})\right)$ react with $\mathrm{Et}{ }_{3} \mathrm{Al}$ via a transmetallation reaction to the corresponding organoaluminium-enamines $\mathrm{Et}_{2} \mathrm{Al}\left[\mathrm{R}^{\prime} \mathrm{N}-\mathrm{CH}=\mathrm{CH}-\mathrm{N}(\mathrm{Et}) \mathrm{R}^{\prime}\right]\left(\mathrm{R}^{\prime}={ }^{t} \mathrm{Bu}(1 \mathrm{c})\right.$, ' $\left.\mathrm{pent}(2 \mathrm{c})\right)$ and $\mathrm{Et}{ }_{2} \mathrm{Zn}$. Prior to the transmetallation reaction initial 1:1 zinc-enamine-trialkylaluminium adducts are formed. Compounds $1 \mathrm{c}$ and $2 \mathrm{c}$ are thermally unstable and rearrange via a 1,2-alkyl shift partly in combination with a hydrogen shift, to $\mathrm{Et}_{2} \mathrm{Al}\left[\mathrm{R}^{\prime} \mathrm{N}=\mathrm{CH}-\mathrm{C}(\mathrm{H}) \mathrm{R}^{\prime}-\mathrm{NEt}\right]$ $\left(R^{\prime}={ }^{t} \mathrm{Bu}(1 \mathrm{~d}),{ }^{\prime}\right.$ pent (2d)) (70\%) and $\mathrm{Et}_{2} \mathrm{Al}\left[\mathrm{R}^{\prime} \mathrm{N}-\mathrm{CH}_{2} \mathrm{CR}^{\prime}=\mathrm{NEt}\right]\left(\mathrm{R}^{\prime}={ }^{\prime} \mathrm{Bu}\right.$ (1e), 'pent (2e)) (30\%). The driving force for the alkyl shift, which is restricted to tertiary alkyl groups, is release of steric strain in the five-membered NCCN aluminium chelate ring.
\end{abstract}

\section{Introduction}

We and others have shown that 1,4-dihetero-1,3butadienes ( $\mathrm{R}^{\prime} \mathrm{N}=\mathrm{CH}-\mathrm{CR}^{\prime \prime}=\mathrm{X} ; \mathrm{X}=\mathrm{NR}^{\prime}, \mathrm{O} ; \mathrm{R}^{\prime}=$ alkyl, aryl; $\mathrm{R}^{\prime \prime}=$ alkyl, aryl, $\mathrm{OMe}, \mathrm{NEt}_{2}$ ), e.g. diimines, imino-ketones, imino-esters and imino-amides are valuable starting materials for the metal-mediated synthesis of several interesting organic compounds, e.g. $\beta$-lactams [1], 2- and 3-pyrrolidinones [2], 1,5-dihydropyrrol-2-ones [3], tetrahydropyrrolopyrroles [4] and indolizines [5].

Diorganozinc $\left(R_{2} \mathrm{Zn}\right)$ and trialkylaluminium $\left(\mathrm{R}_{3} \mathrm{Al}\right)$ compounds have proven to be especially useful reagents for regioselective alkylation of 1,4-dihetero-1,3butadienes. A significant difference between $R_{2} Z n$ and $R_{3} \mathrm{Al}$ reagents in these reactions is the formation of the initial donor-acceptor complexes, prior to the alkylation step. It has been well established that, for example, $\alpha$-diimines $\left(R^{\prime} \mathrm{N}=\mathrm{CH}-\mathrm{CH}=\mathrm{NR}^{\prime},=\mathrm{R}^{\prime} \mathrm{DAB}\right)$ form donor-acceptor complexes with $R_{2} \mathrm{Zn}$ in which the $\mathrm{N}=\mathrm{C}-\mathrm{C}=\mathrm{N}$ moiety is $\sigma, \sigma-N, N$-chelate bonded to the zinc atom in a $s$-cis conformation, $c f$. Scheme 1A [6]. In contrast, with $R_{3} \mathrm{Al}$ this ligand system affords

\footnotetext{
Correspondence to: Prof. Dr. G. van Koten.

* Dedicated to Professor E.O. Fischer on the occasion of this 75th anniversary in admiration of his fine contribution to the field of Organometallic Chemistry.
}

initial complexes in which only one $\mathrm{N}$-atom of the $\alpha$-diimine system is $\sigma$-N-monodentate bonded to the aluminium centre, i.e. in this bonding mode the $\alpha$-diimine ligand is in the $s$-trans conformation, which is also the ground state conformation of $\alpha$-diimines of the type $\mathrm{R}^{\prime} \mathrm{N}=\mathrm{CH}-\mathrm{CH}=\mathrm{NR}^{\prime}, c f$. Scheme $1(\mathrm{~B})[6 \mathrm{~b}, 7]$.

Extensive studies of the reactions of $R_{2} \mathrm{Zn}$ and $R_{3} A l$ with 1,4-diaza-1,3-butadienes ( $R^{\prime} D A B$ ) showed

A
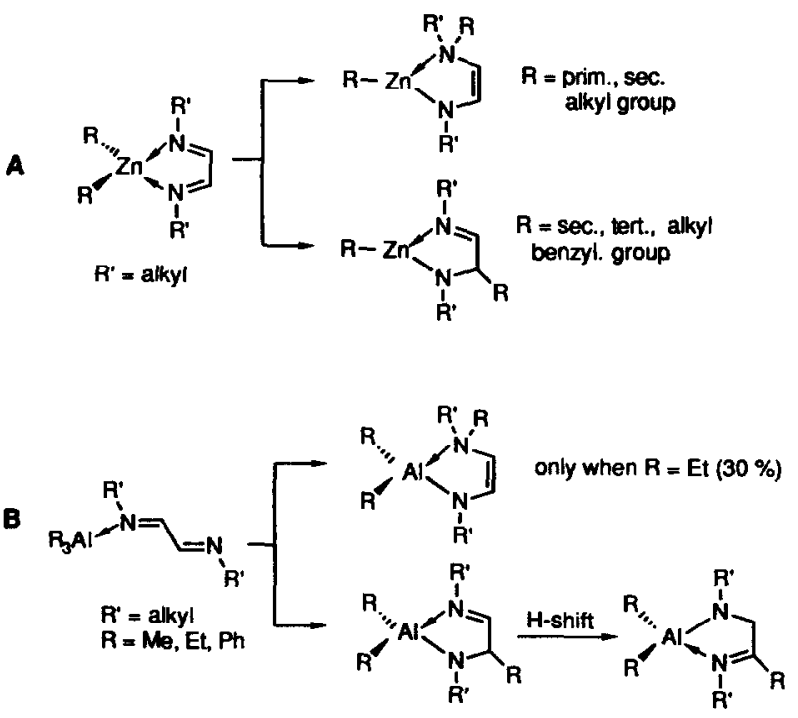

Scheme 1. 
that the subsequent, regioselective R-group transfer step occurring in these reactions is highly dependent on both the metal and the type of $R$ group present in the organometallic reagent. Reaction of di(primaryalkyl)zinc compounds (with the exception of $\mathrm{Me}_{2} \mathrm{Zn}$ ) with $\mathrm{R}^{\prime} \mathrm{DAB}$ affords exclusively the $\mathrm{N}$-alkylated enamine compounds, $c f$. Scheme 1 [6]. (It has been proposed that the formation of $\mathrm{N}$-alkylated products is a result of prior single electron transfer (SET process) in the $\mathrm{Et}_{2} \mathrm{Zn}\left(\mathrm{R}^{\prime} \mathrm{DAB}\right)$ complex [6c].) The reaction of $\mathrm{Et}_{3} \mathrm{Al}$ with $R^{\prime} D A B$ affords a mixture of products, arising from transfer of an ethyl-group from aluminium to either a nitrogen atom, i.e. formation of an organoaluminium-enamine in $30 \%$ yield (see Scheme 1B), or to a carbon atom of the $\mathrm{N}=\mathrm{C}-\mathrm{C}=\mathrm{N}$ skeleton, sometimes followed by what can formally be seen as a 1,2-hydrogen shift, i.e. formation of organoaluminium-iminoamides, in $70 \%$ yield $[7,8]$. In contrast, reactions of $R_{2} \mathrm{Zn}\left(\mathrm{R}=\right.$ tertiary alkyl or benzyl) and $\mathrm{R}_{3} \mathrm{Al}(\mathrm{R}=$ methyl or phenyl) with $R^{\prime} D A B$ are selective and afford products in which the $\mathrm{R}$ group is transferred to one of the imine-C atoms of the $\mathrm{N}=\mathrm{C}-\mathrm{C}=\mathrm{N}$ skeleton, $c f$. Scheme 1(A) and 1(B), respectively [6,7].

Recently we have shown that the N-alkylated products are organozinc-enamines, which are reactive in diastereoselective condensation reactions with aldehydes [9]. In order to study the influence of the metal atom in these metallo-enamines on their reactivity in condensation reactions we reinvestigated the synthesis of organoaluminium-enamines, in particular the reaction of $\mathrm{R}^{\prime} \mathrm{DAB}$ with $\mathrm{Et}_{3} \mathrm{Al}$. We now report the synthesis of pure organoaluminium-enamines via a transmetallation reaction of the organozinc-enamines $\mathrm{EtZn}\left[\mathrm{R}^{\prime} \mathrm{N}-\mathrm{CH}=\mathrm{CH}-\mathrm{N}(\mathrm{Et}) \mathrm{R}^{\prime}\right]$ with $\mathrm{R}_{3} \mathrm{Al}$. Attention is given to a unique 1,2 -alkyl shift $\left[15^{*}\right]$ which occurs in these organoaluminium-enamine complexes, when $\mathbf{R}^{\prime}$ is a tertiary alkyl group, during the attempted purification by distillation.

\section{Results and discussion}

Reaction of the 1,4-diaza-1,3-butadienes ( $R^{\prime} D A B$; $\mathrm{R}^{\prime}={ }^{\mathrm{t}} \mathrm{Bu}(1), \mathrm{R}^{\prime}={ }^{\mathrm{t}}$ pent (2), $\mathbf{R}^{\prime}={ }^{\mathrm{i}} \operatorname{Pr}(3)$ ) with $\mathrm{Et}_{2} \mathrm{Zn}$ affords the organozinc-enamines 1a-3a in quantitative yield ( $c f$. eqn. (1)).

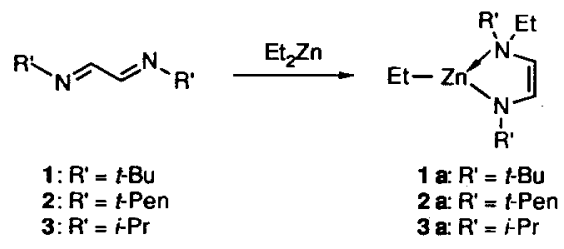

* Reference number with asterisk indicates a note in the list of references.
In a subsequent transmetallation reaction with $\mathrm{Et}_{3} \mathrm{Al}$ these organozinc-enamines $(1 \mathbf{a}-\mathbf{3 a})$ were converted into the corresponding organoaluminium-enamines $1 \mathbf{c}-\mathbf{3 c}$ and $\mathrm{Et}_{2} \mathrm{Zn}$, eqn. (2). The $\mathrm{Et}_{2} \mathrm{Zn}$ product is volatile and could be removed by distillation at reduced pressure at ambient temperature, which afforded the pure organoaluminium compounds $1 \mathbf{c - 3 c}$ as pale yellow oils.

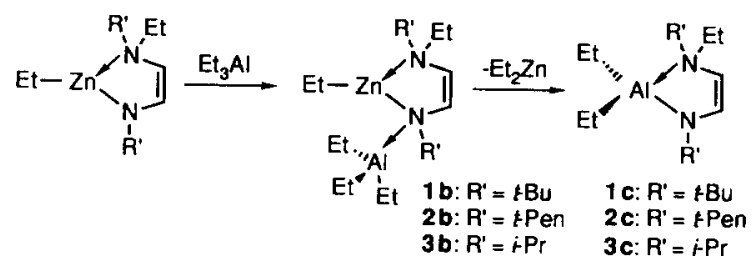

We propose that prior to the transmetallation reaction initial 1:1 zinc-enamine-triethylaluminium adducts (1b-3b) are formed as is shown in eqn. (2). Evidence for such a mixed organozinc-aluminium complex was obtained from a detailed study of the transmetallation reaction of $\mathrm{Me}_{3} \mathrm{Al}$ with $\mathrm{MeZn}\left({ }^{\mathrm{t}} \mathrm{BuN}-\mathrm{CH}=\mathrm{CH}-\right.$ $\left.\mathrm{N}(\mathrm{Et})^{t} \mathrm{Bu}\right)\left(\mathbf{1 a}^{\prime}\right)$. The latter zinc-enamine, which was used as a model compound, was easily obtained via the reaction of $\mathrm{Me}_{2} \mathrm{Zn}$ with ${ }^{\mathrm{t}} \mathrm{Bu}(\mathrm{H}) \mathrm{N}-\mathrm{CH}=\mathrm{CH}-\mathrm{N}(\mathrm{Et})^{t} \mathrm{Bu}$ according to eqn. (3) [6].

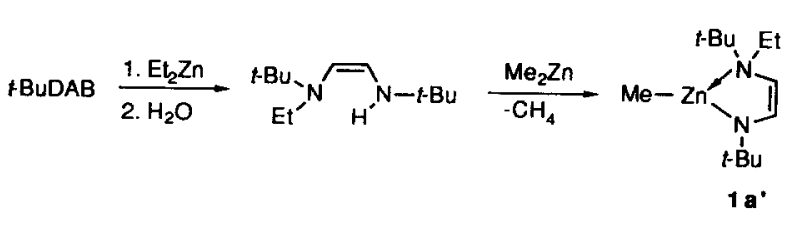

The transmetallation reaction of $1 \mathbf{a}^{\prime}$ with $\mathrm{Me}_{3} \mathrm{Al}$ was followed by ${ }^{1} \mathrm{H}$ NMR spectroscopy in toluene- $d_{8}$. In the ${ }^{1} \mathrm{H}$ NMR spectrum of $1 \mathbf{a}^{\prime}$ the two olefinic resonances are observed as an AB-pattern at 3.96 and $6.82 \mathrm{ppm}$. Immediately after the addition of one equivalent of $\mathrm{Me}_{3} \mathrm{Al}$ the ${ }^{1} \mathrm{H}$ NMR spectrum (recorded at $-30^{\circ} \mathrm{C}$ ) changes considerably. The $A B$ pattern originating from 1a' disappears while a new $A B$ pattern appears at 5.01 and $5.89 \mathrm{ppm}$, which is assigned to the olefinic resonances of the methylzinc-enamine- $\mathrm{Me}_{3} \mathrm{Al}$ adduct $\mathbf{1} \mathbf{b}^{\prime}$, for which a proposed structure is schematically shown in eqn. (4). Furthermore, the resonances of the ethyl group of the $\mathrm{N}(\mathrm{Et})^{\mathrm{t}} \mathrm{Bu}$ moiety are observed as an $\mathrm{ABX}_{3}$ pattern indicating that pyramidal inversion at nitrogen is blocked (on the NMR time-scale) as a result of $\mathrm{N}$-metal coordination. Finally, the ${ }^{1} \mathrm{H}$ resonances of the $\mathrm{Al}-\mathrm{CH}_{3}$ and $\mathrm{Zn}-\mathrm{CH}_{3}$ groups are observed as two single lines in a 3:1 intensity ratio at -0.24 and $-0.10 \mathrm{ppm}$, respectively. Based on these observations alternative structures involving coordination of the $\mathrm{N}(\mathrm{Et})^{\mathrm{t}} \mathrm{Bu}$ group to aluminium and a trans$\mathrm{N}-\mathrm{C}=\mathrm{C}-\mathrm{N}$ moiety may not $a$ priori be excluded. How- 
ever, since the observed ${ }^{3} J\left({ }^{1} \mathrm{H}-{ }^{1} \mathrm{H}\right)$ value of $5.1 \mathrm{~Hz}$ for the olefinic resonances of $1 \mathbf{b}^{\prime}$ unambiguously points to a $c i s-\mathrm{N}-\mathrm{C}=\mathrm{C}-\mathrm{N}$ arrangement such alternative structures seem to be highly unlikely. Furthermore, the ${ }^{13} \mathrm{C}$ NMR data (see Experimental section) obtained for $\mathbf{1 b}^{\prime}$ are in agreement with a structure as proposed in eqn. (4). Compound 1 $\mathbf{1 b}^{\prime}$ ' was isolated as a very unstable white solid material (see Experimental section). When the temperature of a solution of $1 \mathbf{b}^{\prime}$ in toluene- $d_{8}$ is raised to $35^{\circ} \mathrm{C}$ the ${ }^{1} \mathrm{H}$ NMR spectrum shows coalescence of the $\mathrm{Al}-\mathrm{CH}_{3}$ and $\mathrm{Zn}-\mathrm{CH}_{3}$ resonances to one broad single line, indicating that a process involving scrambling of the Me groups at zinc and aluminium becomes operative on the NMR time-scale. On further increasing of the temperature to $40^{\circ} \mathrm{C}$ a rapid irreversible exchange of the alkyl groups bonded to zinc and aluminium occurs, as indicated by the observation of resonances for the organoaluminium-enamine $1 \mathbf{c}^{\prime}$ and free $\mathrm{Me}_{2} \mathrm{Zn}$ in the ${ }^{1} \mathrm{H}$ NMR spectrum.

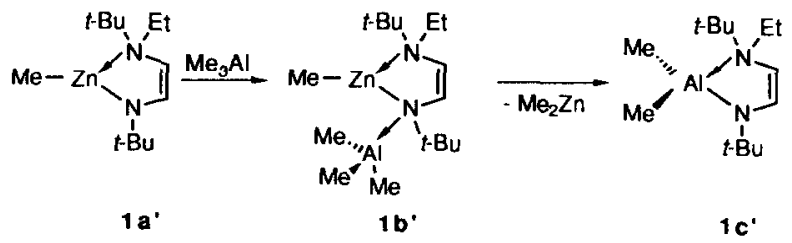

The existence of species like $\mathbf{1 b}-\mathbf{3 b}$ is supported by structures, reported by Robinson and co-workers, in which an additional $R_{3} \mathrm{Al}$ or $\mathrm{R}_{2} \mathrm{AlCl}$ molecule is bound to the amido-nitrogen atom of an organoaluminium amido compound $[10,11]$. In this respect it should also be noted that organoaluminium-enolates of $\mathrm{N}, \mathrm{N}-$ disubstituted glycine ester form complexes with $\mathrm{Me}_{3} \mathrm{Al}$ and $\mathrm{Me}_{2} \mathrm{AlCl}$ via a lone pair of the enolate oxygen atom $[7,14]$.

During the attempted purification of the organoaluminium-enamines $1 c$ and $2 c$ by distillation under reduced pressure a rather unexpected 1,2-alkyl shift occurs (see eqn. (5); $\left[15^{*}\right]$ ). According to their ${ }^{1} \mathrm{H}$ and ${ }^{13} \mathrm{C}$ NMR spectra (see Experimental section) the Nalkylated organoaluminium compounds rearrange to a mixture of $\mathrm{Et}_{2} \mathrm{Al}\left(\mathrm{R}^{\prime} \mathrm{N}=\mathrm{CH}-\mathrm{CH}\left(\mathrm{R}^{\prime}\right)-\mathrm{NEt}\right)$ (1d and 2d) and $\mathrm{Et}_{2} \mathrm{Al}\left(\mathrm{R}^{\prime} \mathrm{N}-\mathrm{CH}_{2}-\mathrm{C}\left(\mathrm{R}^{\prime}\right)=\mathrm{NEt}\right)(1 \mathrm{e}$ and $2 \mathrm{e}), 70 \%$ and $30 \%$, respectively.<smiles>[B]N1C=CN(CC)N1CC</smiles>

$1 \mathrm{c}: \mathrm{R}^{\prime}=\mathrm{t}-\mathrm{Bu}$ 2c: $R^{\prime}=t$ Pen

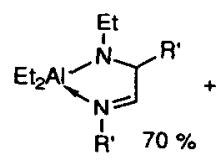

$1 \mathrm{~d}: \mathrm{R}^{\prime}=t \mathrm{Bu}$ 2d: $R^{\prime}=t$ Pen



In both products the tertiary alkyl group, at the amine nitrogen atom in $1 \mathrm{c}$ and $2 \mathrm{c}$, has migrated to the adjacent carbon centre (1d and $\mathbf{2 d}$ ). Furthermore, the formation of the products $1 e$ and $2 e$ reveals that in some cases a subsequent $1,2-\mathrm{H}$-shift has taken place (eqn. (5)). The occurrence of such a $\mathrm{H}$-shift has been observed separately when organoaluminium iminoamido compounds (obtained from the reaction of $\mathrm{R}^{\prime} \mathrm{DAB}$ with $\mathrm{R}_{3} \mathrm{Al}$ ) were heated (vide supra) [7].

Surprisingly, under the same experimental conditions $3 \mathbf{c}\left(\mathrm{R}^{\prime}={ }^{i} \mathrm{Pr}\right)$ does not show this rearrangement reaction. Heating of pure $3 \mathrm{c}$ at $150^{\circ} \mathrm{C}$ does not give rise to products resulting from an alkyl shift, but to extensive decomposition. Obviously, the observed alkyl shift in $1 \mathrm{c}$ and $2 \mathrm{c}$ is unique for tertiary alkyl groups.

The ${ }^{1} \mathrm{H}$ and ${ }^{13} \mathrm{C}$ NMR data (see Experimental section) of 1d-2d and 1e-2e are in agreement with the structures as proposed in eqn. (5). Furthermore, these data are comparable with those of the almost identical compounds $\mathrm{Et}_{2} \mathrm{Al}\left(\mathrm{R}^{\prime} \mathrm{N}=\mathrm{CH}-\mathrm{CH}(\mathrm{Et})-\mathrm{NR}^{\prime}\right)$ and $\mathrm{Et}_{2} \mathrm{Al}\left(\mathrm{R}^{\prime} \mathrm{N}-\mathrm{CH}_{2}-\mathrm{C}(\mathrm{Et})=\mathrm{NR}^{\prime}\right)$, which have been prepared along independent routes involving the reaction of $\mathrm{Et}_{3} \mathrm{Al}$ with $\mathrm{R}^{\prime} \mathrm{DAB}$ (vide supra). Particularly the ${ }^{1} \mathrm{H}$ and ${ }^{13} \mathrm{C}$ resonances of the $\mathrm{N}=\mathrm{CH}-\mathrm{CH}\left(\mathrm{R}^{\prime}\right)-\mathrm{N}$ (in $1 \mathrm{~d}$ and 2d) and $\mathrm{N}-\mathrm{CH}_{2}-\mathrm{C}\left(\mathrm{R}^{\prime}\right)=\mathrm{N}$ moieties (in 1e and 2e) are of importance for the structure assignment. The ${ }^{1} \mathrm{H}$ NMR spectra of 1d and 2d show $\mathrm{N}=\mathrm{CH}$ and $\mathrm{N}-\mathrm{C} H \mathrm{R}$ resonances at 7.90 and $3.35 \mathrm{ppm}$, respectively, with ${ }^{3} J(\mathrm{H}-\mathrm{H})$ of $1.2 \mathrm{~Hz}$, while the ${ }^{13} \mathrm{C}$ NMR spectra show a $\mathrm{N}=\mathrm{CH}$ resonance at $180.0 \mathrm{ppm}$. The ${ }^{1} \mathrm{H}$ NMR spectra of 1e-2e show a singlet at approximately $4.0 \mathrm{ppm}$ for the $\mathrm{NCH}_{2}$ group and the corresponding ${ }^{13} \mathrm{C}$ NMR spectrum shows a resonance for the $\mathrm{N}=C \mathrm{R}$ group at about $221.0 \mathrm{ppm}$. It is most likely that the formation of products like 1e and 2e, resulting from a subsequent 1,2-hydrogen shift $\left[15^{*}\right]$ is a consequence of a thermodynamically controlled equilibrium. The position of this equilibrium is controlled by subtle steric repulsive forces between substituents at the nitrogen and carbon atoms in the five-membered chelate ring as well as the aluminium centre.

A possible driving force for the alkyl shift in 1c and $2 c$ is the release of steric repulsion between substituents in the five-membered chelate ring. As a consequence of the adjacent, tetrahedral ( $\mathrm{sp}^{3}$-hybridized) aluminium- and amino-nitrogen atoms in the fivemembered chelate ring considerable steric repulsion exists between the substituents at these atoms, which, moreover, are almost in an eclipsed conformation. After occurrence of the alkyl shift, a sterically more favourable situation arises, $c f$. $\mathbf{A}$ and $\mathbf{B}$ in Fig. 1. Furthermore, the X-ray crystal structure of $\mathrm{Cl}_{2} \mathrm{Al}\left(\mathrm{EtNC}_{2} \mathrm{H}_{4} \mathrm{NMe}_{2}\right)$, reported by Atwood and coworkers [12], clearly shows that a minor steric repul- 
<smiles>C[R]N1C=CN(CC)[N+]1(CC)CC</smiles><smiles>[R]C1C=NN([Tl])C1(CC)CC</smiles><smiles>[R7]N1C=CN([Tl])[R4]1CC</smiles>

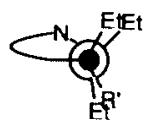

A

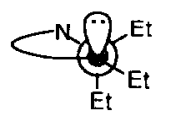

B

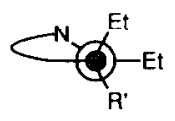

C

Fig. 1. Newman projections along the Al-amido-nitrogen bond in the case of $\mathrm{A}$ and $\mathrm{B}$, and along the $\mathrm{Zn}$-amino-nitrogen bond in the case of $\mathbf{C}$.

sion exists between the $\mathrm{Cl}_{2} \mathrm{Al}$ and the $\mathrm{NEt}$ group in this amido-aluminium compound. The proposal of release of steric repulsion as driving force for the alkyl shift reaction seems corroborated by the fact that similar 1,2-alkyl shifts [15*] are not observed for corresponding organozinc-enamine compounds, e.g. 1a and 2a (vide supra). In the latter compounds steric repulsion between the substituents at zinc and the amino nitrogen atom already is minimal as a consequence of the planar, trigonal geometry around the zinc atom, see $\mathbf{C}$ in Fig. 1.

The exact nature of the alkyl shift reaction (e.g. radical or polar) we do not yet understand. However it is clear from our experiments that this shift only occurs for $\mathbf{R}^{\prime}=$ tertiary alkyl. This observation suggests that a mechanism involving either a radical or a carbocation could be operative as both tertiary carbon radicals and carbocations are stabilized and could be intermediates. Together with the suggested tertiary alkyl radicals or carbocations organoaluminiumNCCN radicals or anions, respectively, are formed (sec Scheme 2), which are both relatively stable. The former have been studied earlier by us and were found to be in equilibrium with their $\mathrm{C}-\mathrm{C}$ coupled dimer and are therefore relatively stable [8]. This could favour a radical mechanism. It therefore seems that a more detailed study of the
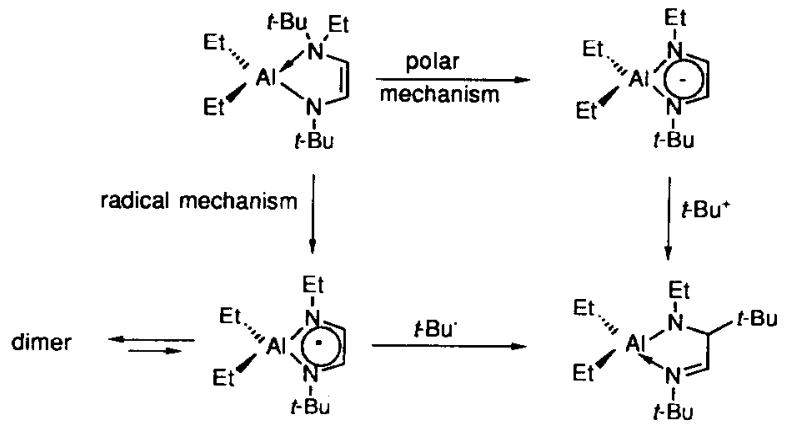

Scheme 2.
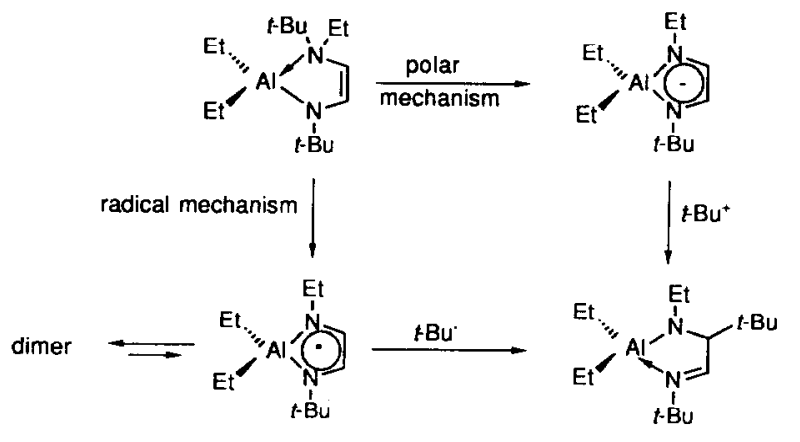<smiles>[R]C(/C=N/[Tl])NCC</smiles>

1d': $R^{1}=R^{2}=k B u$

2d': $\mathbf{R}^{1}=\mathbf{R}^{2}=$ PPen

$1 d^{\prime}: R^{1}=t-B u, R^{2}=\notin$ Pen

$2 d^{\prime}: R^{1}=t$ Pent, $R^{2}=t-B u$

$2 e^{*}: R^{1}=t$ Pen,$R^{2}=t-B$

Fig. 2. The products obtained from hydrolysis of a reaction mixture of $1 \mathrm{c}$ and $2 \mathrm{c}$ after $6 \mathrm{~h}$ at $60^{\circ} \mathrm{C}$.

mechanistic aspects of this unique rcaction is necessary in order to elucidate the mechanism.

To get an indication whether the observed alkyl shift reaction is an inter- or intramolecular process a solution of a $1: 1$ mixture of $1 c\left(R^{\prime}={ }^{t} B u\right)$ and $2 c\left(R^{\prime}=\right.$ 'pent) was exposed to the same experimental conditions $\left(60^{\circ} \mathrm{C}, 6 \mathrm{~h}\right)$ as used earlier in the separate reactions (vide supra). After hydrolysis of the reaction mixture the organic products were analyzed by GC-MS. It appeared that not only the expected products, i.e. $1 \mathbf{d}^{\prime}, \mathbf{2} \mathbf{d}^{\prime}, 1 \mathbf{e}^{\prime}$ and $2 \mathbf{e}^{\prime}$ ( $c f$. Fig. 2), resulting from the hydrolysis of 1d, 2d, $1 \mathrm{c}$ and $2 \mathrm{e}$, respectively, were present but also four other products, i.e. 1d", 2d", 1e" and $2 \mathbf{e}^{\prime \prime}$ (see Fig. 2), resulting from the hydrolysis of the organoaluminium compounds in which one 'Bu and one ${ }^{t}$ pent group are present. This observation indicates that the mechanism of the alkyl shift does not consist exclusively of intramolecular steps but also comprises intermolecular exchange steps.

It is interesting to note that the hydrogen shifted product obtained from the reaction of $\mathrm{Me}_{3} \mathrm{Al}$ with 'BuDAB (see Scheme 3) is only stable as organoaluminium species. In the reaction of $\mathrm{Me}_{3} \mathrm{Al}$ with ${ }^{\mathrm{C}} \mathrm{BuDAB}$ at first the $\mathrm{C}$-alkylated compound $\mathbf{A}$ is formed, which slowly undergoes the hydrogen shift reaction to form $\mathbf{B}$. After hydrolysis of $\mathbf{B}$ the organic product $\mathbf{D}$ rearranges directly to $\mathbf{C}$, which is the same product obtained after hydrolysis of $\mathbf{A}$. Thus, the position of the above suggested thermodynamically controlled equilibrium be- 
tween the C-alkylated product and the hydrogen shift product shifts, in this case, completely to the side of the C-alkylated compound upon hydrolysis of the organoaluminium compound. This effect was not observed for products $1 e$ and $2 e$.

\section{Experimental section}

\subsection{General data}

All experiments were carried out under a dry and oxygen-free nitrogen atmosphere, using standard Schlenk techniques. Solvents were carefully dried and distilled from sodium/benzophenone prior to use. All standard chemicals were purchased from Aldrich or Janssen. ${ }^{1} \mathrm{H}$ and ${ }^{13} \mathrm{C}$ NMR spectra were recorded on a Bruker AC-200 or Bruker AC-300 spectrometer in $\mathrm{C}_{6} \mathrm{D}_{6}$, using TMS as an internal standard $(0.0 \mathrm{ppm})$. The GC-MS analyses were carried out at the Analytical Chemical Laboratory of the University of Utrecht. Elemental analyses were performed by Dornis und Kolbe, Mikroanalytisches Laboratorium, Mülheim a.d. Ruhr, Germany.

3.2 General procedure for the syntheses of organoaluminium-enamine of the type $E t_{2} A l\left(R^{\prime} N C H=\right.$ $\left.C H N(E t) R^{\prime}\right)$

To a stirred solution of $R^{\prime} \mathrm{DAB}\left(\mathbf{R}^{\prime}={ }^{t} \mathrm{Bu}(\mathbf{1}),{ }^{\mathrm{t}}\right.$ pent (2), $\left.{ }^{\mathrm{i}} \operatorname{Pr}(3)\right)(10 \mathrm{mmol})$ in hexane $(25 \mathrm{ml})$ were added successively one equivalent of $\mathrm{Et}_{2} \mathrm{Zn}(10 \mathrm{ml}$ of a $1 \mathrm{M}$ solution in hexane) and one equivalent of $\mathrm{Et}_{3} \mathrm{Al}(10 \mathrm{ml}$ of a $1 \mathrm{M}$ solution in hexane). The mixture was heated for $45 \mathrm{~min}$ at $40^{\circ} \mathrm{C}$. Subsequently the volatile elements (solvent and $\mathrm{Et}_{2} \mathrm{Zn}$ ) of the mixture were removed in vacuo at ambient temperature leaving the organoaluminium-enamines $\mathbf{1 c - 3 c}$ as yellow, air- and moisturesensitive oils in quantitative yield.

${ }^{1} \mathrm{H}$ NMR of $1 \mathrm{c}: \delta 6.33(\mathrm{~d}, J=4.4 \mathrm{~Hz}, 1 \mathrm{H}, \mathrm{CH}=\mathrm{CH})$, $4.01(\mathrm{~d}, J=4.4 \mathrm{~Hz}, 1 \mathrm{H}, \mathrm{CH}=\mathrm{CH}), 2.85,2.29(\mathrm{~m}, 2 \times 1 \mathrm{H}$, $\left.\mathrm{NCH} \mathrm{H}^{\prime} \mathrm{CH}_{3}\right), 1.24\left(\mathrm{t}, 6 \mathrm{H}, \mathrm{Al}\left(\mathrm{CH}_{2} \mathrm{CH}_{3}\right)_{2}\right), 1.13(\mathrm{~s}, 9 \mathrm{H}$, $\left.{ }^{\mathrm{t}} \mathrm{Bu}\right), 1.06\left(\mathrm{t}, 3 \mathrm{H}, \mathrm{NCH}_{2} \mathrm{CH}_{3}\right), 1.03\left(\mathrm{~s}, 9 \mathrm{H},{ }^{\mathrm{t}} \mathrm{Bu}\right), 0.05$ (m, 4H, $\left.\mathrm{Al}\left(\mathrm{CH}_{2}\right)_{2}\right)$.

${ }^{1} \mathrm{H}$ NMR of 2c: (characteristic resonances) $\delta 6.34(\mathrm{~d}$, $J=4.5 \mathrm{~Hz}, 1 \mathrm{H}, \mathrm{CH}=\mathrm{CH}), 4.04(\mathrm{~d}, J=4.5 \mathrm{~Hz}, 1 \mathrm{H}$, $\mathrm{CH}=\mathrm{C} H), 2.94,2.34\left(\mathrm{~m}, 2 \times 1 \mathrm{H}, \mathrm{NCH} H^{\prime} \mathrm{CH}_{3}\right), 1.15(\mathrm{~s}$, $\left.6 \mathrm{H}, \mathrm{NC}\left(\mathrm{CH}_{3}\right)_{2}\right), 1.02,0.91$ (s, $2 \times 3 \mathrm{H}, \mathrm{NC}(\mathrm{Me})\left(\mathrm{Me}^{\prime}\right)$ ). $0.17\left(\mathrm{~m}, 4 \mathrm{H}, \mathrm{Al}\left(\mathrm{CH}_{2}\right)\right)$.

${ }^{1} \mathrm{H}$ NMR of 3c: (characteristic resonances) $\delta 6.28(\mathrm{~d}$, $J=3.9 \mathrm{~Hz}, 1 \mathrm{H}, \mathrm{CH}=\mathrm{CH}), 4.04(\mathrm{~d}, J=3.9 \mathrm{~Hz}, 1 \mathrm{H}$, $\mathrm{CH}=\mathrm{CH}), 3.14\left(\mathrm{~m}, 1 \mathrm{H}, \mathrm{NCH} \mathrm{H}^{\prime} \mathrm{CH}_{3}\right), 3.10(\mathrm{dq}, 1 \mathrm{H}$, $\left.\mathrm{CH}\left(\mathrm{CH}_{3}\right)_{2}\right), 2.62\left(\mathrm{~m}, 1 \mathrm{H}, \mathrm{NCH} H^{\prime} \mathrm{CH}_{3}\right), 2.47(\mathrm{dq}, 1 \mathrm{H}$, $\left.\mathrm{CH}\left(\mathrm{CH}_{3}\right)_{2}\right), 0.15\left(\mathrm{~m}, 4 \mathrm{H}, \mathrm{Al}\left(\mathrm{CH}_{2}\right)\right)$.

\subsection{Alkyl shift reaction}

A solution of $1 \mathrm{c}$ (or $2 \mathrm{c}$ ) in hexane was heated for $6 \mathrm{~h}$ at $60^{\circ} \mathrm{C}$. The solvent was removed leaving a yellow oil, of which the ${ }^{1} \mathrm{H}$ NMR revealed that it was a mixture of two products: $\mathrm{Et}_{2} \mathrm{Al}\left(\mathrm{R}^{\prime} \mathrm{N}=\mathrm{CHCHR} \mathrm{R}^{\prime} \mathrm{NEt}\right)\left(\mathrm{R}^{\prime}={ }^{\mathbf{t}} \mathrm{Bu}\right.$ (1d), $\left.\mathrm{R}^{\prime}=(\mathbf{2 d})\right)(70 \%)$ and $\mathrm{Et}_{2} \mathrm{Al}\left(\mathrm{R}^{\prime} \mathrm{NCH}_{2} \mathrm{CR}^{\prime}=\mathrm{NEt}\right)$ $(30 \%)\left(R^{\prime}={ }^{\prime} B u(1 e), R^{\prime}=' \operatorname{pent}(2 e)\right)$.

${ }^{1} \mathrm{H}$ NMR of 1d: (characteristic resonances) $\delta 7.93$ (d, $J=1.2 \mathrm{~Hz}, \mathrm{~N}=\mathrm{C} H$ ) $3.37(\mathrm{~d}, J=1.2 \mathrm{~Hz}, \mathrm{NC} H) .{ }^{1} \mathrm{H}$ NMR of 1e: (characteristic resonance) $\delta 3.97(\mathrm{~s}, 2 \mathrm{H}$, $\mathrm{NC} \mathrm{H}_{2}$ ). ${ }^{1} \mathrm{H}$ NMR of $2 \mathrm{~d}$ : (characteristic resonances) $\delta$ $7.90(\mathrm{~d}, J=1.2 \mathrm{~Hz}, \mathrm{~N}=\mathrm{C} H), 3.54(\mathrm{~d}, J=1.2 \mathrm{~Hz}, \mathrm{NCH})$. ${ }^{1} \mathrm{H}$ NMR of 2e: (characteristic resonance) $\delta 3.85(\mathrm{~s}$, $2 \mathrm{H}, \mathrm{NCH}_{2}$ ).

\subsection{Cross-over experiment}

A $1: 1$ mixture of $1 \mathrm{c}$ and $2 \mathrm{c}$ in hexane was heated for $6 \mathrm{~h}$ at $60^{\circ} \mathrm{C}$. The mixture was quenched with one equivalent of $\mathrm{H}_{2} \mathrm{O}$ and stirred for an additional hour. The solid material was filtered off affording a yellow solution. The solvent was evaporated in vacuo leaving a yellow oil. The oil was analyzed by GC-MS and contained several products. The main products have a molecular weight of 198 or 226 and some product with a molecular weight of 212 resulting from cross-over of alkyl groups was found. No direct identification of the products was possible.

\subsection{Model compound $\mathrm{MeZn}\left({ }^{t} \mathrm{BuNCH}=\mathrm{CHN}(E t)^{t} \mathrm{Bu}\right)$ $\left(1 a^{\prime}\right)$}

To a stirred solution of $\left({ }^{t} \mathrm{BuN}(\mathrm{H}) \mathrm{CH}=\mathrm{CHN}(\mathrm{Et})^{\mathrm{t}} \mathrm{Bu}\right)$ [6a] $(1.98 \mathrm{~g}, 10 \mathrm{mmol})$ in hexane $(25 \mathrm{ml})$ was added one equivalent of $\mathrm{Me}_{2} \mathrm{Zn}(10 \mathrm{ml}$ of a $1 \mathrm{M}$ solution in hexane). The mixture was heated at $50^{\circ} \mathrm{C}$ for $2 \mathrm{~h}$ and subsequently the solvent was removed to afford a colourless, air- and moisture-sensitive oil in quantitative yield.

${ }^{1} \mathrm{H}$ NMR of 1a': $\delta 6.82(\mathrm{~d}, J=4.5 \mathrm{~Hz}, 1 \mathrm{H}, \mathrm{CH}=\mathrm{CH}$ ), $3.96(\mathrm{~d}, J=4.5 \mathrm{~Hz}, 1 \mathrm{H}, \mathrm{CH}=\mathrm{CH}), 2.81,1.96(\mathrm{~m}, 2 \times 1 \mathrm{H}$, $\left.\mathrm{NCH}^{\prime} \mathrm{H}^{\prime} \mathrm{CH}_{3}\right), 1.24\left(\mathrm{~s}, 9 \mathrm{H},{ }^{\mathrm{t}} \mathrm{Bu}\right), 1.07(\mathrm{t}, 3 \mathrm{H}$, $\left.\mathrm{NCH}_{2} \mathrm{CH}_{3}\right), 1.04\left(\mathrm{~s}, 9 \mathrm{H},{ }^{\mathrm{t}} \mathrm{Bu}\right),-0.15$ (s, 3H, $\left.\mathrm{ZnMe}\right)$. ${ }^{13} \mathrm{C}$ NMR of $1 \mathrm{a}^{\prime}: \delta 143.9(\mathrm{CH}=\mathrm{CH}), 97.7(\mathrm{CH}=\mathrm{CH})$,

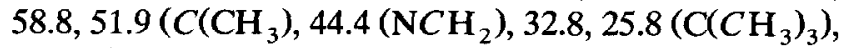
$11.9\left(\mathrm{NCH}_{2} \mathrm{CH}_{3}\right),-10.3\left(\mathrm{ZnCH}_{3}\right)$. Anal. Calcd. $\mathrm{C}_{13} \mathrm{H}_{28} \mathrm{~N}_{2} \mathrm{Zn}$ : C, 56.22; H, 10.16; N, 10.09. Found: $\mathrm{C}$, $56.30 ; \mathrm{H}, 10.12 ; \mathrm{N}, 9.96 \%$.

To a stirred solution of $1 \mathrm{a}^{\prime}(2.77 \mathrm{~g} ; 10 \mathrm{mmol})$ in hexane $(25 \mathrm{ml})$ was added one equivalent of $\mathrm{Me}_{3} \mathrm{Al}$ (5 $\mathrm{ml}$ of a $2 \mathrm{M}$ solution in hexane). The solvent was evaporated in vacuo at ambient temperature, leaving the $1: 1$ organozinc-aluminium complex $\mathrm{MeZn}\left({ }^{\mathrm{t}} \mathrm{Bu}\right.$ $\left.\left(\mathrm{Me}_{3} \mathrm{Al}\right) \mathrm{NCH}=\mathrm{CHN}(\mathrm{Et})^{t} \mathrm{Bu}\right)\left(\mathbf{1}^{\prime}\right)$ as a white solid compound in quantitative yield. ${ }^{1} \mathrm{H}$ NMR of $1 \mathbf{b}^{\prime}$ $\left(-30^{\circ} \mathrm{C}\right.$; toluene- $\left.d_{8}\right): \delta 5.81(\mathrm{~d}, J=5.1 \mathrm{~Hz}, 1 \mathrm{H}$, $\mathrm{C} H=\mathrm{CH}), 4.99(\mathrm{~d}, J=5.1 \mathrm{~Hz}, 1 \mathrm{H}, \mathrm{CH}=\mathrm{CH}), 2.94,2.81$ (m, $\left.2 \times 1 \mathrm{H}, \mathrm{NCH}^{\prime} \mathrm{H}^{\prime} \mathrm{CH}_{3}\right), 1.23\left(\mathrm{~s}, 9 \mathrm{H},{ }^{\mathrm{t}} \mathrm{Bu}\right), 0.80(\mathrm{t}$, $\left.3 \mathrm{H}, \mathrm{NCH}_{2} \mathrm{CH}_{3}\right), 0.79\left(\mathrm{~s}, 9 \mathrm{H},{ }^{\mathrm{t}} \mathrm{Bu}\right),-0.10(\mathrm{~s}, 3 \mathrm{H}$, 
ZnMe), -0.24 (s, 9H, AlMe). ${ }^{13} \mathrm{C}$ NMR of $1 \mathrm{~b}$ : $\delta 138.6$ $(\mathrm{CH}=\mathrm{CH}), 120.5(\mathrm{CH}=\mathrm{CH}), 59.6,57.1\left(\mathrm{C}\left(\mathrm{CH}_{3}\right), 48.6\right.$ $\left.\left(\mathrm{NCH}_{2}\right), 30.1,27.2\left(\mathrm{C} \mathrm{CH}_{3}\right)_{3}\right), 12.7\left(\mathrm{NCH}_{2} \mathrm{CH}_{3}\right),-2.7$ $\left(\mathrm{ZnCH} \mathrm{H}_{3}\right),-5.3$ (AlMe). A solution of $1 \mathbf{b}^{\prime}$ in toluene- $d_{8}$ was heated in a NMR tube for $30 \mathrm{~min}$ at $40^{\circ} \mathrm{C}$ affording $\mathrm{Me}_{2} \mathrm{Al}\left({ }^{\mathrm{t}} \mathrm{BuNCH}=\mathrm{CHN}(\mathrm{Et})^{\prime} \mathrm{Bu}\right)\left(1 \mathrm{c}^{\prime}\right)$ and $\mathrm{Me}_{2} \mathrm{Zn}$. ${ }^{1} \mathrm{H}$ NMR of $1 \mathrm{c}^{\prime}: \delta 6.44(\mathrm{~d}, J=4.4 \mathrm{~Hz}, 1 \mathrm{H}, \mathrm{CH}=\mathrm{CH})$, $4.06(\mathrm{~d}, J=4.4 \mathrm{~Hz}, 1 \mathrm{H}, \mathrm{CH}=\mathrm{CH}), 2.97,2.34(\mathrm{~m}, 2 \times 1 \mathrm{H}$, $\left.\mathrm{NC} \mathrm{HH}^{\prime} \mathrm{CH}_{3}\right), 1.20\left(\mathrm{~s}, 9 \mathrm{H},{ }^{\mathrm{t}} \mathrm{Bu}\right), 1.12(\mathrm{t}, 3 \mathrm{H}$, $\left.\mathrm{NCH}_{2} \mathrm{CH}_{3}\right), 1.07\left(\mathrm{~s}, 9 \mathrm{H},{ }^{\mathrm{t}} \mathrm{Bu}\right),-0.24,-0.35(\mathrm{~s}, 2 \times 3 \mathrm{H}$, AlMe). Anal. Calcd. $\mathrm{C}_{14} \mathrm{H}_{31} \mathrm{~N}_{2} \mathrm{Zn}$ : C, 66.10; $\mathrm{H}, 12.28$; $\mathrm{N}, 11.01$. Found: $\mathrm{C}, 66.12 ; \mathrm{H}, 12.22 ; \mathrm{N}, 11.07 \%$.

\section{Acknowledgement}

This work was supported in part (EW) by the Netherlands Foundation for Chemical Research (SON) with financial aid from the Netherlands Organisation for Advancement of Pure Research (NWO). The authors thank Prof. W. Drenth for helpful discussion.

\section{References and notes}

1 (a) F.H. van der Steen, H. Kleijn, A.L. Spek and G. van Koten, $J$. Org. Chem., 56 (1991) 5868; (b) E. Wissing, S. van der Linden, W.J.J. Smeets, A.L. Spek and G. van Koten, to be published.

2 E. Wissing, J. Bocrsma, M.D. Jansscn, A.L. Spek and G. van Koten, Rec. Trav. Chim. Pays-Bas, (1993) in press.

3 H.-W. Frühauf and F. Seils, J. Organomet. Chem., 323 (1987) 67.

4 P.P.M. de Lange, H.-W. Frühauf, M.J.A. Kraakman, M. van Wijnkoop, M. Kranenburg, A.H.J.P. Groot, K. Vrieze, J. Fraanje, Y. Wang and M. Numan, Organometallics, 12 (1993) 417.
5 E. Wissing, R.W.A. Havenith, J. Boersma and G. van Koten, Tetrahedron Lett., 31 (1992) 7933.

6 (a) J.M. Klerks, J.T.B.H. Jastrzebski, G. van Koten and K. Vrieze, J. Organomet. Chem., 224 (1982) 107; (b) G. van Koten, A. de Meijere and H. tom Dieck (eds.) in; Organometallics in Organic Synthesis, Springer-Verlag, 1987, p. 277; (c) M. Kaupp, H. Stoll, H. Preuss, W. Kaim, T. Stahl, G. van Koten, E. Wissing, W.J.J. Smeets and A.L. Spek, J. Am. Chem. Soc., 113 (1991) 5606: (d) M.R.P. van Vliet, G. van Koten, P. Buysingh, J.T.B.H Jastrzebski and A.L. Spek, Organometallics, 6 (1987) 537; (e) M.R.P. van Vliet, G. van Koten, J.F. Modder, J.A.M. van Beek, W.J. Klaver, K. Goubitz and C.H. Stam, J. Organomet. Chem., 319 (1987) 285; (f) M.R.P. van Vliet, W.J. Klaver, K. Goubitz and G. van Koten, Rec. Trav. Chim. Pays-Bas, 6 (1987) 132.

7 (a) J.M. Klerks, D.J. Stufkens, G. van Koten and K. Vrieze, J. Organomet. Chem., 181 (1979) 271; (b) M.R.P. van Vliet, G. van Koten, M.A. Rotteveel, M. Schrap, K. Vrieze, B. Kojic-Prodic, A.L. Spek and A.J.M. Duisenberg, Organometallics, 5 (1986) 1389; (c) M.R.P. van Vliet, G. van Koten, M.S. de Keijser and K. Vrieze, Organometallics, 6 (1987) 1652.

8 G. van Koten, J.T.B.H. Jastrzebski and K. Vrieze, J. Organomet. Chem., 250 (1983) 49.

9 E. Wissing, R.W.A. Havenith, J. Boersma, W.J.J. Smeets, A.L. Spek and G. van Koten, J. Org. Chem., (1993) in press.

10 G.H. Robinson, A.D. Rae, C.F. Campana and S.K. Byram, Organometallics, 6 (1987) 1227.

11 (a) G.H. Robinson, M.F. Self, S.A. Sangokoya and W.T. Pennington, J. Am. Chem. Soc., 111 (1989) 1520; (b) G.H. Robinson and S.A. Sangokoya, Organometallics, 7 (1988) 1453.

12 M.J. Zaworotko and J.L. Atwood, Inorg. Chem., 19 (1980) 268.

13 O.T. Beachley, Jr. and K.C. Racette, Inorg. Chem., 15 (1976) 2110.

14 F.H. van der Steen, G.P.M. van Mier, A.L. Spek, J. Kroon and G. van Koten, J. Am. Chem. Soc., 113 (1991) 5742.

15 Alternatively, the 1,2-shift could also be a 1,5-shift. 